\title{
Tetranychus urticae changes its oviposition pattern in the presence of the predatory mites, Phytoseiulus persimilis and Typhlodromus bagdasarjani
}

\author{
MONA MOGHADASI, AZADEH ZAHEdi GOlPAYEGANi, AlireZA SABOORI, \\ HOSSEIN ALLAHYARI, HAMIDEH DEHGHANI TAFTI
}

Department of Plant Protection, Faculty of Agriculture, University of Tehran, Karaj, Iran

Corresponding author, e-mails: moghadasi@ut.ac.ir, zahedig@ut.ac.ir, saboori@ut.ac.ir, allahyar@ut.ac.ir

Keywords oviposition, spider mite, predation, parental care, Phytoseiidae

Abstract Oviposition behaviors in herbivorous mites are affected by several factors i.e. food availability for juveniles and reduced predation risks. We used the twospotted spider mite, Tetranychus urticae Koch (Tetranychidae) to find out whether the previous presence of specialist/ generalist phytoseiid predator individuals, Phytoseiulus persimilis Athias-Henriot/ Typhlodromus bagdasarjani Wainstein \& Arutunjan (here, direct effect) or their previous odour perception by prey (here, indirect effect) would affect T. urticae oviposition strategies. Tetranychus urticae female individuals were placed on a leaf disc in a plastic container with predators either on the same disc (direct presence of predator) or on the second disc (receiving odours related to a predator) in the same container. Getting experienced, the prey individuals transferred to the oviposition container to their oviposition pattern parameters get recorded. The ovipositing T. urticae were monitored in two experimental situations: 1 . Receiving odours related to the predator- prey interaction from the second leaf disc in the same oviposition container during their oviposition period, and 2. Receiving no odour. Our results showed that when T. urticae females perceived the predator presence in their first container (with either predator species, both direct and indirect effect), they reduced their total egg distances, oviposition rates and oviposition periods significantly regardless of receiving odours related to prey-predator interactions during experiment. Receiving odours during oviposition, T. urticae females decreased their pairwise egg distances in at least 4 and at most 6 pairs of eggs, while when odours were absent during oviposition, the distances decreased in at least 2 and at most 3 pairs of eggs. The direct presence of $P$. persimilis reduced the prey oviposition period significantly more than that when T. bagdasarjani was present. The spider mites oviposition rate reduction was obviousely more than that in the presence of T. bagdasarjani. The different effects of predator species on T. urticae egg distances were discussed. 


\section{Zmiana wzoru składania jaj przez Tetranychus urticae w obecności drapieżnych roztoczy,} Phytoseiulus persimilis i Typhlodromus bagdasarjani

Słowa kluczowe składanie jaj, przędziorki, drapieżnictwo, opieka rodzicielska, Phytoseiidae

Streszczenie Na zachowania związane ze składaniem jaj roztoczy roślinożernych wpływa kilka czynników między innymi dostępność pokarmu dla młodych osobników i zmniejszone ryzyko drapieżnictwa. Użyliśmy przędziorka Tetranychus urticae Koch (Tetranychidae), aby dowiedzieć się, czy obecność drapieżnika określonego typu (wyspecjalizowany w drapieżnictwie na Tetranychus urticae przedstawiciel drapieżnych dobroczynkowatych, Phytoseiulus persimilis AthiasHenriot i niewyspecjalizowany Typhlodromus bagdasarjani Wainstein \& Arutunjan) wpływają na strategie składania jaj T. urticae. Następnie powtórzyliśmy eksperyment używając zapachu poprzednich ofiar tych drapieżników. Samice Tetranychus urticae umieszczono na krążku z liści w plastikowym pojemniku z drapieżnikami na tym samym krążku (bezpośrednia obecność drapieżnika) lub na drugim krążku (odbierającym zapachy związane z drapieżnikiem) w tym samym pojemniku. Po doświadczeniu, ofiary przenoszono do pojemnika, w którym samice składały jaja. Parametry związane ze składaniem jaj T. urticae monitorowano w dwóch grupach doświadczalnych: grupa eksperymentalna otrzymywała zapach związany z interakcją drapieżnik-ofiara, natomiast grupa kontrolna nie otrzymywała zapachu. Nasze wyniki wykazały, że gdy samice T. urticae dostrzegły obecność drapieżnika lub jego zapach (w przypadku obu gatunków drapieżników), znacznie zmniejszyły liczbę składanych jaj i odległości między składanymi jajami, a ponadto skracały okres składania jaj, niezależnie od aplikowania zapachów związanych z interakcją między drapieżnikiem i ofiarą. Jednak aplikacja zapachu podczas składania jaj powodowała zmniejszenie odległości między składanymi jajami w od 4 do 6 par kolejno składanych jaj. W grupie kontrolnej, odległości zmniejszyły się w od 2 lub 3 parach kolejno składanych jaj. Bezpośrednia obecność $P$. persimilis skróciła okres składania jaj przez ofiarę znacznie bardziej niż obecność T. bagdasarjani. Zmniejszenie szybkości składania jaj przez przędziorki było wyraźnie większe niż w obecności T. bagdasarjani.

\section{Introduction}

Animals with a range of specialist and non-specialist predators are confronted with many time and energy costing risks during their foraging behavior. The behavioral decisions made under the risk of predation are more imperative than those made to detect food (Lima, Dill, 1990). Many organisms show defensive or evasive behaviors when they receive chemical information related to their predators (direct cues of predation risk) or from the conspecifics injured by those predators (indirect cues of predation risk). The prey different reactions in these situations depend on several factors i.e. how familiar the prey is with the alerting cues, the predator risk level and the prey strategies to avoid predator (Grostal, Dicke, 1999). These crucial traits that influence the prey behavior, distribution and whole fitness, could also lead to a range of new indirect interactions in the food web (Abrams, 1996).

Failing to detect a high-risk predator increases the encounter rate of prey with predator which might have important implications on its survival and reproductive success. Several studies have demonstrated that once a predator has been detected, prey changes its behavior so that decrease its vulnerability. The crayfish, Paranephrops zealandicus (Koura) reduced its stationary and walking behavior when it received chemicals related to eel (Anguilla dieffenbachia) (Shave, Townsend, Crowl, 1994). Daphnia magna Straus, respond to chemicals related to its injured conspecifics (crushed Daphnia) by formation of aggregation and vertical distribution towards the bottom (Pijanowska, 1997). The fruit flies (Rhagoletis basiola (Osten Sacken), Tephritidae) delayed their oviposition when received cues related to their egg parasitoid (Hoffmeister, Roitberg, 1997). Dias 
et al. (2016) demonstrated that the response of prey to the cues related to dangerous and harmless predators could be different.

Several studies have demonstrated that when a predator and its con- or hetero-specific competitor are present together, the former should adopt strategies in order to decrease the risk of its offspring being preyed upon. Montserrat et al. (2007) showed that females of Neoseiulus cucumeris (Oudemans) reduced oviposition by retaining eggs inside their body when exposed to Iphiseius degenerans (Berlese). Amblyseius swirskii (Athias-Henriot) could anticipate the possible counterattacks on behalf of Frankliniella occidentalis Pergande and avoided ovipositing near thrips (de Almedia, Janssen, 2013). I. degenerans oviposits away from their food source (pollen) when the predator of its eggs, F. occidentalis was present on the flower (Faraji, Janssen, van Rijn, Sabelis, 2000). Spider mites are known to show anti-predator responses through behaviors such as patch avoidance, induced diapause, reduction of oviposition, producing dense web and moving away from the patch which the predator is present in (Pallini, Janssen, Sabelis, 1999; Choh, Takabayashi, 2006; Kroon, Veenendaal, Bruin, Egas, Sabelis, 2008; Shimoda, Kishimoto, Takabayashi, Amano, Dicke, 2009; Lemos et al., 2010). Dittmann and Schausberger (2017) documented that the aggregated spider mites were less encountered by Phytoseiulus persimilis Athias- Henriot in comparison with the scattered ones. They suggested that more aggregation (inter-individual distance reduction) in T. urticae would lead to more efficacious anti-predator behaviours. Dias et al. (2016) reported that Tetranychus evansi Baker and Pritchard oviposited less and escaped more when their dangerous predator Phytoseiulus longipes Evans was present on the same patch. They concluded that spider mite antipredator behaviours varied with the level of the predator danger. Hackl and Schausberger (2014) were the first who demonstrated that experience and learning could modulate T. urticae anti-predator behaviours. They reported that previous predator experience would lead to a balanced response of T. urticae to P. persimilis cues in the shape of oviposition delay and activity reduction, but not reducing the oviposition rate. They also did not discuss whether the predator perception by T. urticae would lead to the prey oviposition pattern.

Typhlodromus bagdasarjani Wainstein \& Arutunjan is a generalist indigenous phytoseiid mite (Type III) with a wide distribution in the Middle East, especially in the orchards of Iran and reported from plants infested by tetranychids and eriophyids as well as insect pests such as thrips and whiteflies. Various plant exudates, as well as honydew, may serve as supplements which could increase its reproduction potential in food scarcity. T. bagdasarjani could be well adapted to warm climates (Farazmand, Fathipour, Kamali, 2013; Moghadasi, Saboori, Allahyari, Zahedi Golpayegani, 2013; McMurtry, De Moraes, Sourassou, 2013). Phytoseiulus persimilis Athias-Henriot is a specialist (Type I) commercialized predatory mite that is commonly used in ornamental greenhouses to control spider mites. This predatory mite has a short generation time with high fecundity and its post-larval stages are able to attack all stages of T. urticae (Moghadasi et al., 2013; Landeros, Guevara, Badii, Flores, Pamanes, 2004; Pizzol, Poncet, Hector, Ziegler, 2006).

Here, we have investigated the direct and indirect effects of the predatory mites, P. persimilis and T. bagdasarjani on the oviposition rate, distances between eggs and oviposition period of T. urticae. Recording the direct effects, we put the predator female individuals (each species separately) on the same leaf disc which $T$. urticae was present. For indirect effects, no predator was introduced to the spider mite leaf disc, but the ovipositing spider mites received the odours related to interacing prey- predator from the nearby leaf disc in the same container. We tested whether continuing to receive odours during oviposition could also affect $T$. urticae oviposition behavior. We expected that spider mites should reduce the distances between eggs and increase 
their oviposition period when perceived the predator effects. The effect of predator species on the prey strategies is discussed.

\section{Materials and Methods}

\section{Plants and mites}

Rose plants (Rosa hybrida cv. 'blarodje' (Rosaceae)) used in this study were grown in beds under commercial conditions (Cocopeat: Perlit; 60: 40\%) in the greenhouse. Plants were pruned and planted in large plastic pots (25 $\mathrm{cm}$ top diameter, $40 \mathrm{~cm}$ depth and $20 \mathrm{~cm}$ bottom diameter) at $25 \pm 2^{\circ} \mathrm{C}, 65 \pm 10 \% \mathrm{RH}$ and $16 \mathrm{~L}$ : $8 \mathrm{D}$ hour photoperiod. Spider mites, $T$. urticae, were originally collected from infested lima bean cultures in the acarology laboratory at the Department of Plant Protection, Faculty of Agriculture, University of Tehran, Karaj, Iran. Spider mites were transferred onto detached rose leaves placed upside down on water-saturated cotton wool in transparent plastic containers $(20 \times 10 \times 4 \mathrm{~cm})$. The rearing containers were maintained in controlled conditions at $24 \pm 2^{\circ} \mathrm{C}, 60 \pm 5 \% \mathrm{RH}$, and 16L: $8 \mathrm{D}$ hour photoperiod, since three months prior to experiments.

The predatory mites, T. bagdasarjani were collected from black mulberry trees at the campus of Tarbiat Modares University, Tehran, Iran. Phytoseiulus persimilis culture was initially obtained from laboratory stock culture reared at the Acarology laboratory at the Department of Plant Protection, Faculty of Agriculture, University of Tehran, Karaj, Iran. The predatory mites were kept on masses of detached rose leaves deposited upside down on a plastic sheet placed on a water saturated sponge. The plastic sheet was surrounded by napkin tapes which were put into the water from another side so that the predatory mites could drink water. The rearing units were kept at controlled conditions $\left(25 \pm 1^{\circ} \mathrm{C}, 75 \pm 5 \% \mathrm{RH}\right.$ and 16L: 8D hour photoperiod) in a growth chamber. All experiments were carried out at $25-26^{\circ} \mathrm{C}, 75-80 \% \mathrm{RH}$, and 16L: 8D hour photoperiod in growth chamber.

\section{General experimental conditions}

The experimental units consisted of fresh detached rose leaf discs $\left(2 \times 2 \mathrm{~cm}^{2}\right)$ placed upside down on semi-divided water-saturated sponges in a porous ( 8 pore) transparent plastic container (Figure 1). Each pair of cubic sponges was adjusted in a way that the cubes were spaced $15 \mathrm{~mm}$

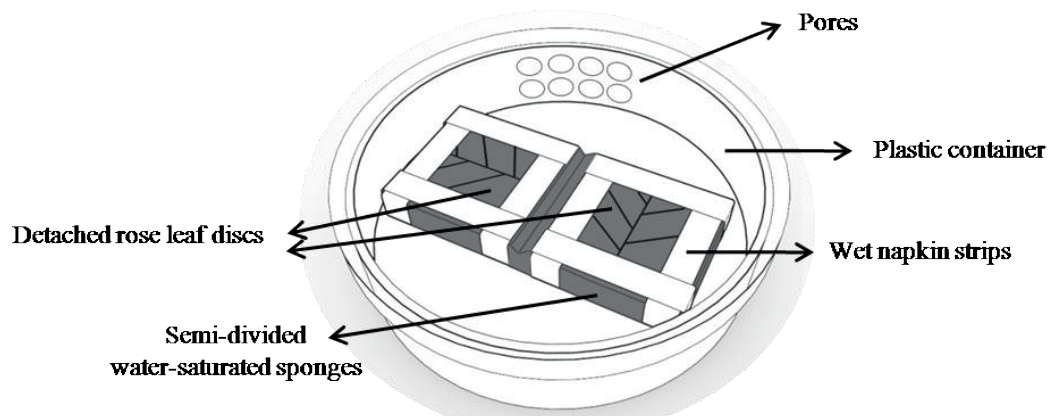

Figure 1. The experimental unit 
from each other. Wet napkin strips were placed around the leaf margins in order to prevent the mites from escaping. Here, the preconditioning plastic container and the oviposition container were considered as the places for the spider mites to get experienced with odors and to check their oviposition behaviors respectively. Depending on the experiments, one of or both of the leaf discs in each container were used.

\section{Experiments}

The oviposition pattern of T. urticae when experienced the predator presence (Direct effect)

Quiescent T. urticae female deutonymphs were selected from the main culture and put on separate leaf discs. After 24 hours, adult same-aged males were introduced to the females for mating. Newly mated T. urticae females were selected randomly (Choh, Uefune, Takabayashi, 2010). Two same-aged predator females (4 days old, predation rate at pick, unpublished data) and 10 same-aged $T$. urticae mated females were introduced to a plastic container (one of the pairwise leaf discs) mentioned above. 24 hours after the predator-prey interactions, one alive T. urticae female was selected randomly and transferred to a new leaf disc singly in a separate container (namely oviposition container) as treatment. Tetranychus urticae mated females (same-aged with those in treatment) which had not experienced the predator presence (in their preconditioning container) were transferred to a new leaf disc (namely oviposition container) singly and considered as control. This experiment was conducted in two situations: 1) When T. urticae females did not receive the odours related to predator-prey interactions in their oviposition container (Figure 2), and 2) when T. urticae females received odours related to predators and prey interactions from the second leaf disc in the same (oviposition) container (Figure 3). The second leaf discs both in the preconditioning (experiencing) and the oviposition container was prepared by introducing three same-aged female predators along with 10 ovipositing T. urticae 24 hours prior to monitoring got started, so that the prey and predators had sufficient time to interact. We kept recording data until

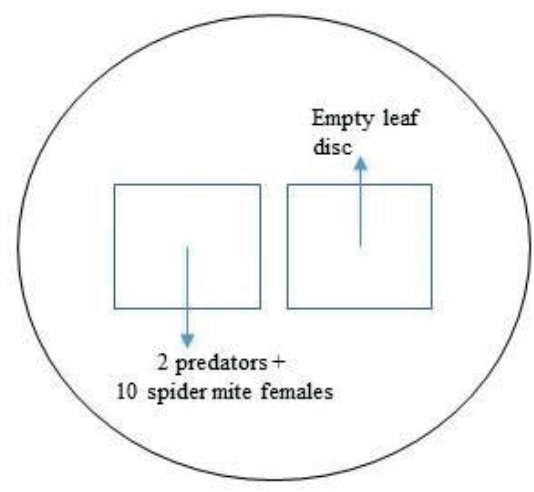

Preconditioning container



Oviposition container

Figure 2. The experimental unit for recording the oviposition behavior of $T$. urticae females when received no odours related to interacting prey and predators (Direct effect) 
the female spider mites died. Data were recorded for T. urticae as follows: a) Total number of eggs each female oviposited till its death, b) Pairwise and total egg distances by regular monitoring, c) The oviposition period of spider mite females. The oviposition priority of eggs was shown by different watercolor spots put beside them. Distances were measured by ruler under binocular microscope (Schausberger, 2005). Each experiment was replicated 20 times.

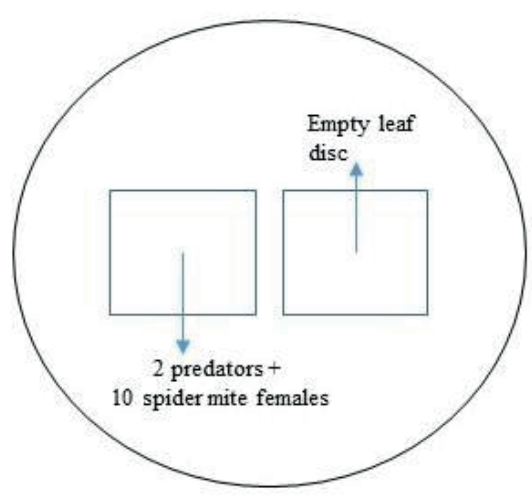

Preconditioning container

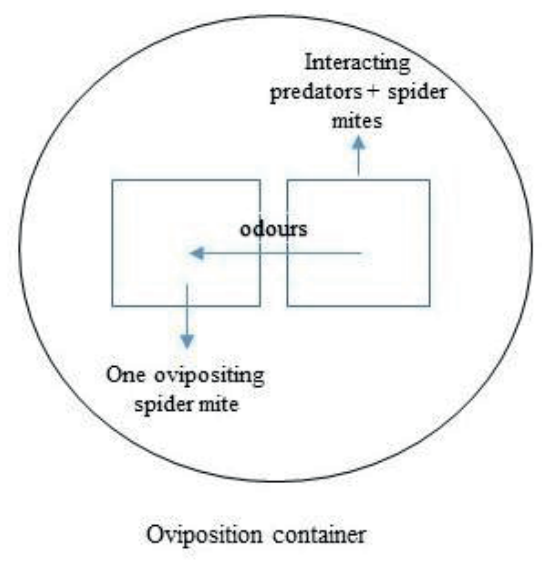

Figure 3. The experimental unit for recording the oviposition behavior of T. urticae females when received odours related to interacting prey and predators from the second leaf disc (Direct effect)

\section{The oviposition pattern of T. urticae when experienced volatiles related to the predator (Indirect effect)}

Two same-aged predator females (4 days old, predation rate at the pick, unpublished data) and 10 same-aged $T$. urticae mated females were introduced into a plastic container (one of the pairwise leaf discs). The second leaf disc of the container was infested by 10 T. urticae mated females (without predators). As both discs were kept in the same container (mentioned above), the spider mite females of the second leaf disc received the odours related to the interactions among their conspecifics with the predators in the first leaf disc. After 24 hours, one T. urticae was selected from the second leaf disc randomly and transferred to a new leaf disc in a new (oviposition) container (treatment). Tetranychus urticae mated females (same-aged with those in treatment) which had just experienced the odours related to conspecifics interactions, were transferred to their oviposition container singly and considered as control. This experiment was conducted in two situations: 1) When T. urticae females did not receive the odours related to predator-prey interactions in their second (oviposition) container, and 2) when T. urticae female in the oviposition container (during oviposition) received odours related to predator-prey interactions from the second leaf disc of the same container. We kept recording data until the female spider mites died. Data were recorded for T. urticae as follows: a) The total number of eggs each female oviposited till its death, b) pairwise and total egg distances by regular monitoring (just for the first seven oviposited eggs as recording such data for the whole (30-40) eggs would be timeconsuming), c) The oviposition period of spider mite females. The oviposition priority of eggs 
was shown by different watercolor spots put beside them. Distances were measured by ruler under binocular. Each experiment was replicated 20 times.

\section{Data analysis}

The oviposition parameters of $T$. urticae in the presence of $P$. persimilis were recorded simultaneously with those in the presence of T. bagdasarjani. Independent sample-test was performed to compare the total number of eggs, oviposition period and pairwise and total egg distance between treatments as well as between each treatment and control using SPSS 16.

\section{Results}

\section{The oviposition pattern of $T$. urticae when experienced the predator presence (Direct effect)}

\section{Receiving no odours in the oviposition container during oviposition}

When T. urticae females experienced the predator (either P. persimilis or T. bagdasarjani) presence in their preconditioning container, they reduced pairwise distances between their first three eggs significantly (Tables 1 and 2, $P<0.01$ ). The pairwise distances between their $4^{\text {th }}$ to $7^{\text {th }}$ eggs did not show any significant difference $(P>0.05)$. Tetranychus urticae total egg distances were significantly shorter when the females experienced the predator presence before starting oviposition (Table $1, P<0.05$ ) (Table $2, P<0.01$ ). Also, $T$. urticae females laid significant fewer eggs when they previously had perceived the predator presence (Tables 1 and 2, $P<0.01$ ). The oviposition periods also decreased when the females experienced the predator presence prior to oviposition (Tables 1 and 2, $P<0.01$ ).

Table 1. The total number of eggs, egg distances $(\mathrm{mm})$ and oviposition period (day) of T. urticae females when experienced $P$. persimilis presence in their preconditioning container

\begin{tabular}{|lc|c|c|c|}
\hline \multicolumn{2}{|c|}{ Source of variation } & $\begin{array}{c}\text { Predator presence } \\
\text { (Mean } \pm \text { SE) }\end{array}$ & $\begin{array}{c}\text { Control } \\
\text { (Mean } \pm \text { SE) }\end{array}$ & $P$ \\
\hline & $1-2$ & $7.7 \pm 0.73$ & $11.8 \pm 1.18$ & $0.005^{* *}$ \\
Pairwise egg & $2-3$ & $7.45 \pm 0.71$ & $10.4 \pm 1.02$ & $0.022^{* *}$ \\
distances & $3-4$ & $6.57 \pm 0.74$ & $11.22 \pm 0.88$ & $0.000^{* *}$ \\
& $4-5$ & $7.72 \pm 0.75$ & $8.02 \pm 1.04$ & 0.816 \\
& $5-6$ & $8.4 \pm 0.42$ & $7.95 \pm 0.84$ & 0.641 \\
\hline Total egg distance $(1-7)$ & $6-7$ & $8.27 \pm 0.42$ & $8.17 \pm 0.65$ & 0.898 \\
Mean of egg distances & & $46.12 \pm 2.65$ & $57.58 \pm 3.31$ & $0.010^{*}$ \\
Total number of eggs & & $7.67 \pm 0.44$ & $9.59 \pm 0.55$ & $0.010^{*}$ \\
Oviposition period & $24.15 \pm 1.02$ & $34.7 \pm 1.69$ & $0.000^{* *}$ \\
\hline
\end{tabular}


Table 2. The total number of eggs, egg distances ( $\mathrm{mm}$ ) and oviposition period (day) of T. urticae females when experienced T. bagdasarjani presence in their preconditioning container

\begin{tabular}{|lc|c|c|c|}
\hline \multicolumn{2}{|c|}{ Source of variation } & $\begin{array}{c}\text { Predator presence } \\
(\text { Mean } \pm \text { SE) }\end{array}$ & $\begin{array}{c}\text { Control } \\
\text { (Mean } \pm \text { SE) }\end{array}$ & $P$ \\
\hline & $1-2$ & $7.22 \pm 0.69$ & $11.8 \pm 1.18$ & $0.002^{* *}$ \\
Pairwise egg & $2-3$ & $6.82 \pm 0.82$ & $10.4 \pm 1.02$ & $0.009^{* *}$ \\
distances & $3-4$ & $7.45 \pm 0.69$ & $11.22 \pm 0.88$ & $0.002^{* *}$ \\
& $4-5$ & $8.07 \pm 0.62$ & $8.02 \pm 1.04$ & 0.967 \\
& $5-6$ & $8.4 \pm 0.75$ & $7.95 \pm 0.84$ & 0.697 \\
\hline Total egg distance (1-7) & $6-7$ & $7 \pm 0.66$ & $8.17 \pm 0.65$ & 0.213 \\
Mean of egg distances & & $74.97 \pm 2.99$ & $57.58 \pm 3.31$ & $0.010^{*}$ \\
Total number of eggs & $25.49 \pm 0.49$ & $9.59 \pm 0.55$ & $0.008^{*}$ \\
Oviposition period & $10.75 \pm 0.09$ & $34.7 \pm 1.69$ & $0.000^{* *}$ \\
\hline
\end{tabular}

The pairwise estimated distances from the $1^{\text {st }}$ to the $7^{\text {th }} T$. urticae eggs did not differ significantly when they experienced either $P$. persimilis or T. bagdasarjani. This was also true for their total egg distances (Table 3, $P<0.05$ ). Although the total number of $T$. urticae eggs was lower in the presence of $P$. persimilis in comparison with in the presence of $T$. bagdasarjani, no significant difference was observed between them $(P<0.05)$. The oviposition period of females also did not show any significant difference in the presence of each of the predators (Table 3, $P>0.05$ ).

Table 3. The total number of eggs, egg distances ( $\mathrm{mm}$ ) and oviposition period (day) of T. urticae females when experienced either $P$. persimilis or $T$. bagdasarjani presence in their preconditioning container

\begin{tabular}{|c|c|c|c|c|}
\hline \multicolumn{2}{|c|}{ Source of variation } & $\begin{array}{l}\text { P. persimilis presence } \\
(\text { Mean } \pm \mathrm{SE})\end{array}$ & $\begin{array}{l}\text { T. bagdasarjani presence } \\
(\text { Mean } \pm \text { SE) }\end{array}$ & $P$ \\
\hline \multirow{6}{*}{$\begin{array}{l}\text { Pairwise egg } \\
\text { distances }\end{array}$} & $1-2$ & $7.7 \pm 0.73$ & $7.22 \pm 0.69$ & 0.637 \\
\hline & $2-3$ & $7.45 \pm 0.71$ & $6.82 \pm 0.82$ & 0.569 \\
\hline & $3-4$ & $6.57 \pm 0.74$ & $7.45 \pm 0.69$ & 0.395 \\
\hline & $4-5$ & $7.72 \pm 0.75$ & $8.07 \pm 0.62$ & 0.721 \\
\hline & $5-6$ & $8.4 \pm 0.42$ & $8.4 \pm 0.75$ & 1.000 \\
\hline & $6-7$ & $8.27 \pm 0.42$ & $7 \pm 0.66$ & 0.113 \\
\hline \multicolumn{2}{|c|}{ Total egg distance (1-7) } & $46.12 \pm 2.65$ & $44.97 \pm 2.99$ & 0.775 \\
\hline \multicolumn{2}{|c|}{ Mean of egg distances } & $7.69 \pm 0.44$ & $7.49 \pm 0.49$ & 0.778 \\
\hline \multicolumn{2}{|c|}{ Total number of eggs } & $24.15 \pm 1.02$ & $25.55 \pm 1.38$ & 0.422 \\
\hline \multicolumn{2}{|c|}{ Oviposition period } & $10.45 \pm 0.11$ & $10.75 \pm 0.09$ & 0.055 \\
\hline
\end{tabular}

\section{Receiving predator-prey odours during oviposition}

In the treatments which T. urticae females not only had experienced the predator (P. persimilis) presence in their preconditioning container, but also received odours related to predatorprey interactions from the second leaf disc of the oviposition container (during oviposition), the pairwise distances between the $1^{\text {st }}$ to the $7^{\text {th }}$ eggs were decreased whereas the distance reduction between the $4^{\text {th }}$ and $5^{\text {th }}$ eggs was not significant (Table 4). Tetranychus urticae total egg distance, 
the total number of eggs and oviposition period were significantly reduced by receiving predatorprey odours during oviposition (Table $4, P<0.01$ ).

Table 4. The total number of eggs, egg distances $(\mathrm{mm})$ and oviposition period (day) of T. urticae females when experienced $P$. persimilis in their proconditioning container and received predator-prey odours during oviposition

\begin{tabular}{|c|c|c|c|c|}
\hline \multicolumn{2}{|c|}{ Source of variation } & $\begin{array}{l}\text { Predator presence } \\
\quad(\text { Mean } \pm \text { SE) }\end{array}$ & $\begin{array}{c}\text { Control } \\
(\text { Mean } \pm \text { SE) }\end{array}$ & $P$ \\
\hline \multirow{6}{*}{$\begin{array}{l}\text { Pairwise egg } \\
\text { distances }\end{array}$} & $1-2$ & $5 \pm 0.69$ & $10.7 \pm 1.14$ & $0.000 * *$ \\
\hline & $2-3$ & $6.4 \pm 0.66$ & $10.27 \pm 0.91$ & $0.001 * *$ \\
\hline & $3-4$ & $5.5 \pm 0.93$ & $10.97 \pm 0.93$ & $0.000 * *$ \\
\hline & $4-5$ & $5.9 \pm 0.99$ & $8.6 \pm 0.93$ & 0.054 \\
\hline & $5-6$ & $5.3 \pm 0.53$ & $8.7 \pm 0.67$ & $0.000 * *$ \\
\hline & $6-7$ & $6.8 \pm 0.58$ & $8.45 \pm 0.52$ & $0.041 *$ \\
\hline \multicolumn{2}{|c|}{ Total egg distance (1-7) } & $34.9 \pm 3.43$ & $57.7 \pm 3.45$ & $0.000^{* *}$ \\
\hline \multicolumn{2}{|c|}{ Mean of egg distances } & $5.82 \pm 0.57$ & $9.62 \pm 0.57$ & $0.000^{* *}$ \\
\hline \multicolumn{2}{|c|}{ Total number of eggs } & $19.4 \pm 0.59$ & $34.45 \pm 1.7$ & $0.000^{* *}$ \\
\hline \multicolumn{2}{|c|}{ Oviposition period } & $10.6 \pm 0.15$ & $11.7 \pm 0.10$ & $0.000 * *$ \\
\hline
\end{tabular}

Receiving odours related to T. bagdasarjani-T. urticae interactions from the second leaf disc of the oviposition container (during oviposition), T. urticae females reduced the pairwise distances between their $1^{\text {st }}$ to $4^{\text {th }}$ and $6^{\text {th }}$ to $7^{\text {th }}$ eggs significantly when they experienced T. bagdasarjani in their preconditioning container (Table 5). Although the distances between the eggs $4^{\text {th }}$ to $5^{\text {th }}$ and $5^{\text {th }}$ to $6^{\text {th }}$ were reduced in comparison with control, the differences were not significant. Tetranychus urticae total egg distance, the total number of eggs and oviposition period were significantly reduced by receiving predator-prey odours during oviposition (Table $5, P<0.01$ ).

Table 5. The total number of eggs, egg distances $(\mathrm{mm})$ and oviposition period (day) of T. urticae females when experienced T. bagdasarjani in their preconditioning container and received predator-prey odours during oviposition

\begin{tabular}{|c|c|c|c|c|}
\hline \multicolumn{2}{|c|}{ Source of variation } & $\begin{array}{c}\text { Predator presence } \\
\quad(\text { Mean } \pm \text { SE) }\end{array}$ & $\begin{array}{c}\text { Control } \\
(\text { Mean } \pm \text { SE) }\end{array}$ & $P$ \\
\hline \multirow{6}{*}{$\begin{array}{l}\text { Pairwise egg } \\
\text { distances }\end{array}$} & $1-2$ & $5.95 \pm 1.04$ & $10.7 \pm 1.14$ & $0.004 * *$ \\
\hline & $2-3$ & $6.55 \pm 1.04$ & $10.27 \pm 0.91$ & $0.011 *$ \\
\hline & $3-4$ & $7.12 \pm 0.96$ & $10.97 \pm 0.93$ & $0.006^{* *}$ \\
\hline & $4-5$ & $6.72 \pm 0.87$ & $8.6 \pm 0.93$ & 0.148 \\
\hline & $5-6$ & $7.95 \pm 0.92$ & $8.7 \pm 0.67$ & 0.514 \\
\hline & $6-7$ & $6.07 \pm 0.70$ & $8.45 \pm 0.52$ & $0.010^{*}$ \\
\hline \multicolumn{2}{|c|}{ Total egg distance (1-7) } & $40.37 \pm 3.55$ & $57.7 \pm 3.45$ & $0.001 * *$ \\
\hline \multicolumn{2}{|c|}{ Mean of egg distances } & $6.73 \pm 0.59$ & $9.62 \pm 0.57$ & $0.001 * *$ \\
\hline \multicolumn{2}{|c|}{ Total number of eggs } & $24.55 \pm 1.7$ & $34.45 \pm 1.7$ & $0.000^{* *}$ \\
\hline \multicolumn{2}{|c|}{ Oviposition period } & $10.75 \pm 0.12$ & $11.7 \pm 0.10$ & $0.000 * *$ \\
\hline
\end{tabular}

The pairwise estimated distances from the $1^{\text {st }}$ to the $7^{\text {th }} T$. urticae eggs did not differ significantly when they experienced either P. persimilis or T. bagdasarjani. This was also true for 
their total egg distances (Table 6, $P<0.05$ ). The total number of $T$. urticae eggs was lower in the presence of $P$. persimilis $(P<0.05)$. The oviposition period of females also did not show any significant difference in the presence of each of the predators (Table $6, P>0.05$ ).

Table 6. The total number of eggs, egg distances ( $\mathrm{mm}$ ) and oviposition period (day) of T. urticae females when experienced either $P$. persimilis or $T$. bagdasarjani presence in their preconditioning container and received the same predator-prey odours during oviposition

\begin{tabular}{|c|c|c|c|c|}
\hline \multicolumn{2}{|c|}{ Source of variation } & $\begin{array}{l}\text { P. persimilis presence } \\
(\text { Mean } \pm \mathrm{SE})\end{array}$ & $\begin{array}{c}\text { T. bagdasarjani presence } \\
(\text { Mean } \pm \mathrm{SE})\end{array}$ & $P$ \\
\hline \multirow{6}{*}{$\begin{array}{l}\text { Pairwise egg } \\
\text { distances }\end{array}$} & $1-2$ & $5 \pm 0.69$ & $5.95 \pm 1.04$ & 0.454 \\
\hline & $2-3$ & $6.4 \pm 0.66$ & $6.55 \pm 1.04$ & 0.904 \\
\hline & $3-4$ & $5.5 \pm 0.93$ & $7.12 \pm 0.96$ & 0.232 \\
\hline & $4-5$ & $5.9 \pm 0.99$ & $6.72 \pm 0.87$ & 0.535 \\
\hline & $5-6$ & $5.3 \pm 0.53$ & $7.95 \pm 0.92$ & $0.017 *$ \\
\hline & $6-7$ & $6.8 \pm 0.58$ & $6.07 \pm 0.70$ & 0.430 \\
\hline \multicolumn{2}{|c|}{ Total egg distance (1-7) } & $34.9 \pm 3.43$ & $40.37 \pm 3.55$ & 0.274 \\
\hline \multicolumn{2}{|c|}{ Mean of egg distances } & $5.82 \pm 0.57$ & $6.73 \pm 0.59$ & 0.274 \\
\hline \multicolumn{2}{|c|}{ Total number of eggs } & $19.4 \pm 0.59$ & $24.55 \pm 1.7$ & $0.007 *$ \\
\hline \multicolumn{2}{|c|}{ Oviposition period } & $10.6 \pm 0.15$ & $10.75 \pm 0.12$ & 0.448 \\
\hline
\end{tabular}

\section{The oviposition pattern of $T$. urticae when received odours related to the predator- prey interactions in their preconditioning container (Indirect effect)}

\section{Receiving no odours in the oviposition container during oviposition}

When $T$. urticae females experienced the presence of $P$. persimilis in their preconditioning container, they reduced their pairwise distances between their 1st and $2 \mathrm{nd}(P<0.05)$ and $3^{\text {rd }}$ and $4^{\text {th }}$ $(P<0.01)$ eggs significantly (Table 7$)$. The pairwise distances between their $4^{\text {th }}$ to $7^{\text {th }}$ eggs did not show any significant difference $(P>0.05)$ and the distances between $2^{\text {nd }}$ and $3^{\text {rd }}$ eggs did likewise. Tetranychus urticae total egg distance was significantly shorter when the females had experienced $P$. persimilis presence prior to oviposition (Table 7, $P<0.05$ ), also $T$. urticae females preferred to lay significant fewer eggs when they previously had perceived the predator presence (Table 7 , $P<0.01)$. The oviposition period also decreased when the female spider mites had experienced $P$. persimilis prior to oviposition (Table $7, P<0.01$ ).

When T. urticae females experienced the presence of T. bagdasarjani in their preconditioning container, they reduced their pairwise distances between their $1^{\text {st }}$ to $3^{\text {rd }}$ eggs significantly (Table $8, P<0.05$ ). The pairwise distances between their $4^{\text {th }}$ to $7^{\text {th }}$ eggs did not show any significant difference $(P>0.05)$. Tetranychus urticae total egg distance was significantly shorter when the females had experienced $T$. bagdasarjani presence prior to oviposition (Table $8, P<0.05$ ), also T. urticae females preferred to lay significant fewer eggs when they previously had perceived the predator presence (Table $8, P<0.01$ ). The oviposition period also decreased when the female spider mites had experienced $T$. bagdasarjani prior to oviposition (Table $8, P<0.01$ ). 
Table 7. The total number of eggs, egg distances (mm) and oviposition period (day) of T. urticae females when received odours related to predator ( $P$. persimilis)-prey interactions in their preconditioning container

\begin{tabular}{|c|c|c|c|c|}
\hline \multicolumn{2}{|c|}{ Source of variation } & $\begin{array}{c}\text { Predator presence } \\
\quad(\text { Mean } \pm \text { SE) }\end{array}$ & $\begin{array}{c}\text { Control } \\
(\text { Mean } \pm \text { SE) }\end{array}$ & $P$ \\
\hline \multirow{6}{*}{$\begin{array}{l}\text { Pairwise egg } \\
\text { distances }\end{array}$} & $1-2$ & $8.2 \pm 0.82$ & $11.2 \pm 1.02$ & $0.028 *$ \\
\hline & $2-3$ & $7.82 \pm 0.79$ & $10.3 \pm 1.04$ & 0.066 \\
\hline & $3-4$ & $6.9 \pm 0.88$ & $11.45 \pm 0.98$ & $0.001 *$ \\
\hline & $4-5$ & $8.15 \pm 0.79$ & $9.47 \pm 1.01$ & 0.311 \\
\hline & $5-6$ & $9.07 \pm 0.51$ & $7.47 \pm 0.81$ & 0.102 \\
\hline & $6-7$ & $8.42 \pm 0.59$ & $8.97 \pm 0.80$ & 0.583 \\
\hline \multicolumn{2}{|c|}{ Total egg distance (1-7) } & $48.57 \pm 2.68$ & $58.87 \pm 3.41$ & $0.023 *$ \\
\hline \multicolumn{2}{|c|}{ Mean of egg distances } & $8.09 \pm 0.45$ & $9.81 \pm 0.57$ & $0.023 *$ \\
\hline \multicolumn{2}{|c|}{ Total number of eggs } & $22.7 \pm 0.75$ & $35.35 \pm 1.68$ & $0.000^{* *}$ \\
\hline \multicolumn{2}{|c|}{ Oviposition period } & $10.45 \pm 0.15$ & $12.2 \pm 0.18$ & $0.000^{* *}$ \\
\hline
\end{tabular}

Table 8. The total number of eggs, egg distances ( $\mathrm{mm}$ ) and oviposition period (day) of T. urticae females when received odours related to predator (T. bagdasarjani)-prey interactions in their preconditioning container

\begin{tabular}{|c|c|c|c|c|}
\hline \multicolumn{2}{|c|}{ Source of variation } & $\begin{array}{l}\text { Predator presence } \\
\quad(\text { Mean } \pm \text { SE })\end{array}$ & $\begin{array}{c}\text { Control } \\
(\text { Mean } \pm \text { SE })\end{array}$ & $P$ \\
\hline \multirow{6}{*}{$\begin{array}{l}\text { Pairwise egg } \\
\text { distances }\end{array}$} & $1-2$ & $8.1 \pm 0.71$ & $11.2 \pm 1.02$ & $0.017 *$ \\
\hline & $2-3$ & $7 \pm 0.77$ & $10.3 \pm 1.04$ & $0.015^{*}$ \\
\hline & $3-4$ & $8.27 \pm 0.87$ & $11.45 \pm 0.98$ & $0.021^{*}$ \\
\hline & $4-5$ & $9.12 \pm 0.79$ & $9.47 \pm 1.01$ & 0.788 \\
\hline & $5-6$ & $9.07 \pm 0.84$ & $7.47 \pm 0.81$ & 0.178 \\
\hline & $6-7$ & $7.35 \pm 0.79$ & $8.97 \pm 0.80$ & 0.159 \\
\hline \multicolumn{2}{|c|}{ Total egg distance (1-7) } & $48.92 \pm 2.69$ & $58.87 \pm 3.41$ & $0.028^{*}$ \\
\hline \multicolumn{2}{|c|}{ Mean of egg distances } & $8.15 \pm 0.45$ & $9.81 \pm 0.57$ & $0.028^{*}$ \\
\hline \multicolumn{2}{|c|}{ Total number of eggs } & $26.5 \pm 1.43$ & $35.35 \pm 1.68$ & $0.000 * *$ \\
\hline \multicolumn{2}{|c|}{ Oviposition period } & $10.6 \pm 0.13$ & $12.2 \pm 0.18$ & $0.000 * *$ \\
\hline
\end{tabular}

Table 9. The total number of eggs, egg distances $(\mathrm{mm})$ and oviposition period (day) of T. urticae females when experienced odours related to predator ( $P$. persimilis /T. bagdasarjani)-prey interactions in their procontioning container

\begin{tabular}{|c|c|c|c|c|}
\hline \multicolumn{2}{|c|}{ Source of variation } & $\begin{array}{l}\text { P. persimilis presence } \\
(\text { Mean } \pm \mathrm{SE})\end{array}$ & $\begin{array}{l}\text { T. bagdasarjani presence } \\
(\text { Mean } \pm \text { SE })\end{array}$ & $P$ \\
\hline \multirow{6}{*}{$\begin{array}{l}\text { Pairwise egg } \\
\text { distances }\end{array}$} & $1-2$ & $8.2 \pm 0.82$ & $8.1 \pm 0.71$ & 0.927 \\
\hline & $2-3$ & $7.82 \pm 0.79$ & $7 \pm 0.77$ & 0.461 \\
\hline & $3-4$ & $6.9 \pm 0.88$ & $8.27 \pm 0.87$ & 0.273 \\
\hline & $4-5$ & $8.15 \pm 0.79$ & $9.12 \pm 0.79$ & 0.392 \\
\hline & $5-6$ & $9.07 \pm 0.51$ & $9.07 \pm 0.84$ & 1.000 \\
\hline & $6-7$ & $8.42 \pm 0.59$ & $7.35 \pm 0.79$ & 0.284 \\
\hline \multirow{4}{*}{\multicolumn{2}{|c|}{$\begin{array}{l}\text { Total egg distance (1-7) } \\
\text { Mean of egg distances } \\
\text { Total number of eggs } \\
\text { Oviposition period }\end{array}$}} & $48.57 \pm 2.68$ & $48.92 \pm 2.69$ & 0.927 \\
\hline & & $8.09 \pm 0.45$ & $8.15 \pm 0.45$ & 0.926 \\
\hline & & $22.7 \pm 0.75$ & $26.5 \pm 1.43$ & $0.024 *$ \\
\hline & & $10.45 \pm 0.15$ & $10.6 \pm 0.13$ & 0.466 \\
\hline
\end{tabular}


The pairwise estimated distances from the $1^{\text {st }}$ to the $7^{\text {th }} T$. urticae eggs did not differ significantly between the treatments which received odours related to P. persimilis or T. bagdasarjani. It was also happened for their total egg distances (Table $9, P<0.05$ ). The total number of $T$. urticae eggs was lower in the presence of $P$. persimilis $(P<0.05)$. The oviposition period of females also did not show any significant difference in the presence of each of the predators (Table $9, P>0.05$ ).

\section{Receiving predator-prey odours during oviposition}

In the treatments which T. urticae females not only had experienced the predator (P. persimilis) presence in their preconditioning container but also received odours related to predator-prey interactions from the second leaf disc of the oviposition container (during oviposition), the pairwise distances between the $1^{\text {st }}$ to the $7^{\text {th }}$ eggs were decreased significantly (Table 10). Tetranychus urticae total egg distance, the total number of eggs and oviposition period were significantly reduced by receiving predator-prey odours during oviposition (Table 10, $P<0.01$ ).

Table 10. The total number of eggs, egg distances ( $\mathrm{mm}$ ) and oviposition period (day) of T. urticae females when received odours related to predator ( $P$. persimilis)-prey interactions in their preconditioning and oviposition containers

\begin{tabular}{|c|c|c|c|c|}
\hline \multicolumn{2}{|c|}{ Source of variation } & $\begin{array}{l}\text { Predator presence } \\
\quad(\text { Mean } \pm \text { SE })\end{array}$ & $\begin{array}{c}\text { Control } \\
(\text { Mean } \pm \text { SE) }\end{array}$ & $P$ \\
\hline \multirow{6}{*}{$\begin{array}{l}\text { Pairwise egg } \\
\text { distances }\end{array}$} & $1-2$ & $5.17 \pm 0.71$ & $10.15 \pm 1.34$ & $0.002 * *$ \\
\hline & $2-3$ & $6.05 \pm 0.61$ & $10.32 \pm 0.93$ & $0.000 * *$ \\
\hline & $3-4$ & $4.85 \pm 0.83$ & $10.7 \pm 1.11$ & $0.000 * *$ \\
\hline & $4-5$ & $5.87 \pm 0.80$ & $8.46 \pm 0.78$ & $0.026^{*}$ \\
\hline & $5-6$ & $4.72 \pm 0.57$ & $8.22 \pm 0.69$ & $0.000^{* *}$ \\
\hline & $6-7$ & $6.95 \pm 0.57$ & $8.57 \pm 0.55$ & $0.049^{*}$ \\
\hline \multicolumn{2}{|c|}{ Total egg distance (1-7) } & $33.62 \pm 2.73$ & $56.44 \pm 3.16$ & $0.000^{* *}$ \\
\hline \multicolumn{2}{|c|}{ Mean of egg distances } & $5.6 \pm 0.45$ & $9.41 \pm 0.53$ & $0.000^{* *}$ \\
\hline \multicolumn{2}{|c|}{ Total number of eggs } & $19.2 \pm 0.71$ & $33.55 \pm 1.77$ & $0.000^{* *}$ \\
\hline \multicolumn{2}{|c|}{ Oviposition period } & $10.15 \pm 0.21$ & $11.4 \pm 0.15$ & $0.000^{* *}$ \\
\hline
\end{tabular}

Receiving odours related to T. bagdasarjani-T. urticae interactions during oviposition, T. urticae females reduced the pairwise distances between their $1^{\text {st }}$ to $4^{\text {th }}$ and $6^{\text {th }}$ to $7^{\text {th }}$ eggs significantly when they experienced T. bagdasarjani in their preconditioning container (Table 11). Although the distances between the eggs $4^{\text {th }}$ to $5^{\text {th }}$ and $5^{\text {th }}$ to $6^{\text {th }}$ were reduced in comparison with control, the differences were not significant. Tetranychus urticae total egg distance, the total number of eggs and oviposition period were significantly reduced by receiving predator-prey odours during oviposition (Table $11, P<0.01$ ).

The pairwise estimated distances from the $1^{\text {st }}$ to the $7^{\text {th }}$ T. urticae eggs did not differ significantly $(P>0.05)$ except the distances between the $5^{\text {th }}$ and $6^{\text {th }}$ eggs $(P<0.01)$ between the treatments which received odours related to $P$. persimilis and $T$. bagdasarjani. It was also happened for their total egg distances (Table 12, $P>0.05$ ). The total number of T. urticae eggs was lower in the presence of $P$. persimilis $(P<0.05)$. The oviposition period of females also did not show any significant difference in the presence of each of the predators (Table 12, $P>0.05$ ). 
Table 11. The total number of eggs, egg distances ( $\mathrm{mm}$ ) and oviposition period (day) of T. urticae females when received odours related to predator (T. bagdasarjani)-prey interactions in their preconditioning and oviposition containers

\begin{tabular}{|l|c|c|c|c|}
\hline \multicolumn{2}{|c|}{ Source of variation } & $\begin{array}{c}\text { Predator presence } \\
\text { (Mean } \pm \text { SE) }\end{array}$ & $\begin{array}{c}\text { Control } \\
\text { (Mean } \pm \text { SE) }\end{array}$ & $P$ \\
\hline \multirow{4}{*}{$\begin{array}{l}\text { Pairwise egg } \\
\text { distances }\end{array}$} & $1-2$ & $5.75 \pm 1.05$ & $10.15 \pm 1.34$ & $0.014^{*}$ \\
\cline { 2 - 5 } & $2-3$ & $6.62 \pm 1.07$ & $10.32 \pm 0.93$ & $0.013^{*}$ \\
\cline { 2 - 5 } & $3-4$ & $6.57 \pm 1.09$ & $10.7 \pm 1.11$ & $0.012^{*}$ \\
\cline { 2 - 5 } & $4-5$ & $6.57 \pm 1.07$ & $8.46 \pm 0.78$ & 0.162 \\
\cline { 2 - 5 } & $5-6$ & $7.67 \pm 0.89$ & $8.22 \pm 0.69$ & 0.629 \\
\cline { 2 - 5 } & $6-7$ & $6.47 \pm 0.72$ & $8.57 \pm 0.55$ & $0.026^{*}$ \\
\hline Total egg distance (1-7) & $39.67 \pm 3.57$ & $56.44 \pm 3.16$ & $0.001^{* *}$ \\
\hline Mean of egg distances & $6.61 \pm 0.59$ & $9.41 \pm 0.53$ & $0.001^{* *}$ \\
\hline Total number of eggs & $23.75 \pm 1.66$ & $33.55 \pm 1.77$ & $0.000^{* *}$ \\
\hline Oviposition period & $10.15 \pm 0.18$ & $11.4 \pm 0.15$ & \\
\hline
\end{tabular}

Table 12. The total number of eggs, egg distances (mm) and oviposition period (day) of T. urticae females when received odours related to predator ( $P$. persimilis /T. bagdasarjani)-prey interactions in their preconditioning and oviposition containers

\begin{tabular}{|lc|c|c|c|}
\hline \multicolumn{2}{|c|}{ Source of variation } & $\begin{array}{c}\text { P. persimilis presence } \\
\text { (Mean } \pm \text { SE) }\end{array}$ & $\begin{array}{c}\text { T. bagdasarjani presence } \\
\text { (Mean } \pm \text { SE) }\end{array}$ & $P$ \\
\hline & $1-2$ & $5.17 \pm 0.71$ & $5.75 \pm 1.05$ & 0.652 \\
Pairwise egg & $2-3$ & $6.05 \pm 0.61$ & $6.62 \pm 1.07$ & 0.643 \\
distances & $3-4$ & $4.85 \pm 0.83$ & $6.57 \pm 1.09$ & 0.217 \\
& $4-5$ & $5.87 \pm 0.80$ & $6.57 \pm 1.07$ & 0.604 \\
& $5-6$ & $4.72 \pm 0.57$ & $7.67 \pm 0.89$ & $0.008^{*}$ \\
\hline Total egg distance $(1-7)$ & $6-7$ & $6.95 \pm 0.57$ & $6.47 \pm 0.72$ & 0.608 \\
Mean of egg distances & $33.62 \pm 2.73$ & $39.67 \pm 3.57$ & 0.187 \\
Total number of eggs & $5.6 \pm 0.45$ & $6.61 \pm 0.59$ & 0.187 \\
Oviposition period & $19.2 \pm 0.71$ & $23.75 \pm 1.66$ & 0.016 \\
\hline
\end{tabular}

\section{Discussion}

Our experiments showed that when T. urticae females perceived the presence of a predator (either P. persimilis or T. bagdasarjani) directly in their predonditioning container, they reduced their oviposition rate, either when they received the odours related to predator during oviposition or even when no signal related to predator was present in their oviposition container. Our suggestion is that the spider mites here have had direct (predator cues) and indirect (dead conspecifics) means of predation risk recognition. This is in consistent with Grostal and Dicke (1999) who demonstrated that fewer spider mites foraged and laid eggs on predator exposed discs in comparison with the discs with intact conspecifics. Lemos et al. (2010) also demonstrated that although Tetranychus evansi Baker \& Pritchard web mediated anti-predator behavior, the prey 
did not produce denser webs when received cues related to their predator, Phytoseiulus longipes Evans, but laid more eggs in the web far from the predator foraging area.

According to our observations, $T$. urticae females put significantly fewer eggs when perceived the presence of $P$. persimilis (in their preconditioning container) in comparison with when T. bagdasarjani (an indigenous species) was present. Our interpretation is that T. urticae females interacted with each of the predator species for 24 hours before their oviposition pattern started to be recorded. During this period, T. bagdasarjani might have been recognized as a less harmful predator or a predator that could not deal with the prey web structure as well as $P$. persimilis. This probable short time experience (Hackl, Schuasberger, 2014) could lead to a higher oviposition rate of T. urticae in the oviposition container especially when no predator (T. bagdasarjani) or no cues related to predator was present in. This is similar to Lemos et al. (2010) who demonstrated that some predators (namely P. persimilis) could cope with the silken web produced by their prey. As far as we know, no published data is present about the reaction of T. bagdasarjani to T. urticae web structure.

In the treatments which T. urticae females not only had experienced the predator (P. persimilis/ T. bagdasarjani) presence in their preconditioning container but received odours related to predator-prey interactions in their oviposition container, they reduced their oviposition rate remarkably. This reduction was more perceptible when $P$. persimilis was chosen as predator species (approx. 44\% in comparison with control). Although again the significant reduction of T. urticae oviposition rate was clear in the presence of $T$. bagdasarjani $(25.55 \pm 6.2)$ receiving odours during oviposition did not affect the reduction of oviposition rate (24.55 \pm 7.6$)$ significantly $(\mathrm{t}=0.455, \mathrm{df}=38, P=0.652)$.

Receiving odours related to predator-prey interactions in the preconditioning container (instead of predator direct presence) led to a significant reduction in T. urticae oviposition rates both when the ovipositing females did not receive any odour in their oviposition container and when they still perceived cues related to predator- prey interactions during oviposition. This is similar to Skaloudova, Zemek and Krivan (2007) who demonstrated that prey reduced its activities (i.e. searching for food) when received the cues related to its predator, so that the physiological changes, happened due to food shortage, reduced its oviposition rate. They also exposed T. urticae to various cues of predator and observed that as much as the risk would increase the oviposition rate would decrease. Choh et al. (2010) also confirmed that spider mites laid less egg in the presence of predators, although the predator cues alone (without the prey presence) could not elicit such a response in spider mites.

In our experiments, the significant gap between the oviposition rates in the presence of odours related to P. persimilis-T. urticae interactions and in the presence of odours related to T. bagdasarjani-T. urticae interactions were narrower in comparison with that recorded in the first series of experiments (direct effect). It seems that when female T. urticae directly interacted with its predator and conspecifics which had affected by predator (first series of experiments), especially $P$. persimilis, it changed its oviposition rate more strictly.

Egg placement and egg aggregation by a mother has mostly investigated in predators and parasitoiids who need to avoid kin cannibalism (Lopez-Sepulcre, Kokko, 2002; Schausberger, 2005). Faraji et al. (2000) showed that females of Iphiseius degenerans produced eggs in clusters (an extreme form of egg aggregation, Schausberger, 2005) and related females deposited eggs closer than the unrelated ones did. Chittenden and Saito (2001) demonstrated that phytoseiid mites with greater number of eggs lay eggs closer to each other. To our knowledge, rare investigations have targeted the egg aggregation in herbivorous mites. Thus our study is of the first providing 
evidence that females of $T$. urticae tend to lay eggs in significantly closer distances from each other when they realize the predator (either P. persimilis or T. bagdasarjani) presence. Interpreting the significant reduced pairwise distances between eggs mostly recorded from the eggs $1-4$ and not-significant distances mostly recorded from the latest ones, we need to design new experiments.

Our results showed that when $T$. urticae females received odours related to predator-prey interactions in their oviposition patch, regardless of being affected by predator directly or indirectly (in their preconditioning container), they decreased the pairwise egg distances in at least 4 and at most 6 pairs of eggs, while when odours were absent in the oviposition container, the distances decreased in at least 2 and at most 3 pairs of eggs. Thus it seems important for the ovipositing T. urticae to perceive risk at the time of (in coincident with) laying eggs. When T. urticae females lay their eggs closer to each other, they reduce their movement activity during oviposition and consequently the female exposure to the predator and the risk of predation would decrease. Little is known about whether the time of risk experience would affect the spider mite oviposition pattern. Zeraatkar, Zahedi Golpayegani and Saboori (2013) discussed the effect of relatedness on egg distances in three samples of $P$. persimilis. They found that when two female predators were introduced to the same patch, the distance of second female eggs from the first ones was not affected by kinship. Chittenden and Saito (2001) reported about the variation in egg-laying patterns between the species of Phytoseiidae and correlated the feeding type and egg distances but, rare documents have reported the variation of oviposition pattern in spider mites or even any herbivorous mite species.

Several studies have demonstrated the effect of prey mite species on the biological aspects of the predators (Dicke, Sabelis, de Jong, 1988; Gnanvossou, Yaninek, Hanna, Dicke, 2003) but to our knowledge, little information has addressed whether the predator species could alter that in spider mites. Hackl and Schausberger (2014) noted delayed and/or decreased oviposition could be of typical antipredator responses of spider mites. Fernández Ferrari and Schausberger (2013) showed that T. urticae laid fewer eggs in the presence of cues of P. persimilis and Amblyseius andersoni, but they did not investigate the probable changes of prey oviposition period in such situations. Our study showed that the oviposition period of T. urticae was reduced significantly either in direct predator (P. persimilis/ T. bagdasarjani) presence or when females received odours related to predator-prey interactions in their preconditioning container, even if the odours were not present in their second container. Although T. urticae oviposition period was shorter in the treatments with $P$. persimilis (in comparison with those with $T$. bagdasarjani), this difference was only significant in the direct presence of a predator, when the odours related to predator-prey interactions were present in the oviposition container. Reducing the oviposition period along with less oviposition rate (mentioned previously) could be considered as an adopted strategy to decrease the risk of predation.

Predation could change the behavior, biology and morphological characters of prey individuals. As a response, prey could develop a wide range of adaptations to reduce the risk of predation. It is known that spider mites are able to detect predators by chemical cues they receive (Grostal, Dicke 1999). Here, we showed that such recognition could induce some types of antipredator behaviors, i.e. oviposition rate reduction, manipulating the distances between eggs and reducing the oviposition period. Our results are of rarely published information about the antipredator behaviors of spider mites. 


\section{Acknowledgement}

We are grateful to Masoud Rezaei Adariany for his valuable help in rose cultivation. The project was partly supported by a grant from "Center of Excellence of Biological Control of Pests", Department of Plant Protection, Faculty of Agriculture, University of Tehran, Karaj, Iran, which is greatly appreciated.

\section{References}

Abrams, P.A. (1996). Dynamics and interactions in food webs with adaptive foragers. In: G.A. Polis, K.O. (eds.), Winemiller Food webs: Integration of patterns and dynmics (pp. 149-159). New York: Chapman and Hall.

Chittenden, A.R., Saito, Y. (2001). Why are there feeding and nonfeeding larvae in phytoseiid mites (Acari, Phytoseiidae)? Journal of Ethology, 19, 55-62.

Choh, Y., Takabayashi, J. (2006). Intact lima bean plants exposed to herbivore-induced plant volatiles attract predatory mites and spider mites at different levels according to plant parts. Applied Entomology and Zoology, 41, 537-543.

Choh, Y., Uefune, M., Takabayashi, J. (2010). Predation-related odours reduce oviposition in a herbivorous mite. Experimental and Applied Acarology, 50, 1-8.

De Almedia, Â.A., Janssen, A. (2013). Juvenile prey induce antipredator behavior in adult predators. Experimental and Applied Acarology, 59, 275-282.

Dias, C.R., Guimarães Bernardo, A.M., Mencalha, J., Freitas, C.W.C., Sarmento, R.A., Pallini, A., Janssen, A. (2016). Experimental and Applied Acarology, 69 (3), 263-276.

Dicke, M., Sabelis, M.W., de Jong, M. (1988). Analysis of prey preference in phytoseiid mites by using an olfactometer, predation models and electrophoresis. Experimental and Applied Acarology, 5, 225-241.

Dittmann, L., Schausberger, P. (2017). Adaptive aggregation by spider mites under predation risk. Scientific Reports, 7, 10609. DOI: 10.1038/s41598-017-10819-8.

Faraji, F., Janssen, A., van Rijn, P.C.J., Sabelis, M.W. (2000). Kin recognition by the predatory mite Iphiseius degenerans: discrimination among own, conspecific, and heterospecific eggs. Ecological Entomology, 25, 147-155.

Farazmand, A., Fathipour, Y., Kamali, K. (2013). Predation preference of Neoseiulus californicus and Typhlodromus bagdasarjani on heterospecific phytoseiid and Scolothrips longicornis in presence and absence of Tetranychus urticae. Persian Journal of Acarology, 2 (1), 181-188.

Fernández Ferrari, M.C., Schausberger, P. (2013). From repulsion to attraction: species- and spatial contextdependent threat sensitive response of the spider mite Tetranychus urticae to predatory mite cues. Naturwissenchaften, 100, 541-549.

Gnanvossou, D., Yaninek, J.S., Hanna, R., Dicke, M. (2003). Effects of prey mite species on life history of the phytoseiid predators Typhlodromalus manihoti and Typhlodromalus aripo. Experimental and Applied Acarology, 30, 265-278.

Grostal, P., Dicke, M. (1999). Direct and indirect cues of predation risk influence behavior and reproduction of prey: A case for acarine interactions. Behavioral Ecology, 10 (4), 422-427.

Hackl, T., Schausberger, P. (2014). Learned predation risk management by spider mites. Ecology and Evolution, 2, 1-7.

Hoffmeister, T.S., Roitberg, B.D. (1997). Counterespionage in an insect herbivore-parasitoid system. Naturwissenchaften, 84, 1-3. 
Kroon, A., Veenendaal, R.L., Bruin, J., Egas, M., Sabelis, M.W. (2008). "Sleeping with the enemy" - predator induced diapause in a mite. Naturwissenschaften, 95, 1195-1198.

Landeros, J., Guevara, L.P., Badii, M.H., Flores, A.E., Pamanes, A. (2004). Effect of different densities of the two spotted spider mite Tetranychus urticae on $\mathrm{CO}_{2}$ assimilation, transpiration, and stomatal behavior in rose leaves. Experimental and Applied Acarology, 32, 187-198.

Lemos, F., Sarmento, R.A., Pallini, A., Dias, A.R., Sabelis, M.W., Janssen, A. (2010). Spider mite we mediatesanti-predator behavior. Experimental and Applied Acarology, 52, 1-10.

Lima, S.L., Dill, L.M. (1990). Behavioral decisions made under the risk of predation: a review and prospectus. Canadian Journal of Zoology, 68, 619-640.

Lopez-sepulcre, A., Kokko, H. (2002). The role of kin recognition in the evolution of conspecific brood parasitism. Animal Behavior, 64, 215-222.

McMurtry, J.A., De Moraes, G.J., Sourassou, N.F. (2013). Revision of the lifestyles of phytoseiid mites (Acari: Phytoseiidae) and implications for biological control strategies. Systematic and Applied Acarology, 18 (4): 297-320.

Moghadasi, M., Saboori, A., Allahyari, H., Zahedi Golpayegani, A. (2013). Prey stages preference of different stages of Typhlodromus bagdasarjani (Acari: Phytoseiidae) to Tetranychus urticae (Acari: Tetranychidae) on rose. Persian Journal of Acarology, 2 (3), 531-538.

Montserrat, M., Bas, C., Magalhaes, S., Sabelis, M.W., de Roos, A.M., Janssen, A. (2007). Predators induce egg retention in prey. Behavioural Ecology, 150, 699-705.

Pallini, A., Janssen, A., Sabelis, M.W. (1999). Spider mites avoid plants with predators. Experimental and Applied Acarology, 23, 803-815.

Pizzol, J., Poncet, C., Hector, S., Ziegler, M. (2006). Preventive IPM for greenhouse roses in the South of France. Bulletin OILB/SROP, 29 (4), 31-36.

Pijanowska, J. (1997). Alarm signals in Daphnia. Oecologia, 112, 12-16.

Schausberger, P. (2005). The predatory mite Phytoseiulus persimilis manipulates imprinting among offspring through egg placement. Behavioral Ecology and Sociobiology, 58, 53-59.

Shave, C.R., Townsend, C.R., Crowl, T.A. (1994). Anti-predator behaviours of a freshwater crayfish (Paranephrops zealandicus) to a native and an introduced predator. New Zealand Journal of Ecology, $18(1), 1-10$.

Shimoda, T., Kishimoto, H., Takabayashi, J., Amano, H., Dicke, M. (2009). Comparison of thread-cutting behavior in three specialist predatory mites to cope with complex webs of Tetranychus spider mites. Experimental and Applied Acarology, 47, 111-120.

Skaloudova, B., Zemek, R., Krivan, V. (2007). The effect of predation risk on an acarine system. Animal Behaviour, 74, 813-821.

Zeraatkar, A., Zahedi Golpayegani, A., Saboori, A. (2013). Kin recognition in three samples of Phytoseiulus persimilis (Acari: Phytoseiidae). Persian Journal of Acarology, 2 (2), 311-319.

Cite as: Moghadasi, M., Zahedi Golpayegani, A., Saboori, A., Allahyari, H., Dehghani Tafti, H. (2019). Tetranychus urticae changes its oviposition pattern in the presence of the predatory mites, Phytoseiulus persimilis and Typhlodromus bagdasarjani. Acta Biologica, 26, 65-81. DOI: 10.18276/ab.2019.26-07. 